\title{
Development and validation of an analytical method for pyrimisulfan determination in agricultural commodities by LC-MS/MS
}

\author{
Jung-Ah Do, Mi-Young Lee, Yoon-Jae Cho, Iil-hyun Kang, Kisung Kwon and Jae-Ho Oh ${ }^{\star}$ \\ Food Chemical Residues Division, National Institute of Food and Drug Safety Evaluation, KFDA, \\ Osong, Cheongwon, Chungbuk 363-700, Korea \\ (Received December 24, 2012; Revised February 12, 2013; Accepted February 12, 2013)
}

\section{LC-MS/MS를 이용한 농산물 중 pyrimisulfan 잔류량 분석법 개발 및 확인}

\author{
도정아·이미영 · 조윤제·강일현 · 권기성 · 오재호` \\ 식품의약품안전청 식품의약품안전평가원 화학물질과 \\ (2012. 12. 24. 접수, 2013. 2. 12. 수정, 2013. 2. 12. 승인)
}

\begin{abstract}
The maximum residue limits of pyrimisulfan is set as $0.05 \mathrm{mg} / \mathrm{kg}$ in rice in 2011 , so very reliable and sensitive analytical method for pyrimisulfan residues is required for ensuring the food safety of pyrimisulfan residues in agricultural products. In this study, a rapid and sensitive analytical method was developed and validated using liquid chromatography electrospray ionization tandem mass spectrometry (LC-MS/MS) for the determination of herbicide pyrimisulfan residues in agricultural products. Average recoveries of pyrimisulfan ranged from 88.7 to $99.3 \%$ at the spiked level of $0.005 \mathrm{mg} / \mathrm{kg}$ and from 90.1 to $94.2 \%$ at the spiked level of $0.05 \mathrm{mg} / \mathrm{kg}$, while the relative standard deviation was less than $10 \%$. Linear range of pyrimisulfan was between $0.01 \sim 1.0 \mu \mathrm{g} / \mathrm{mL}$ with the correlation coefficient $\left(r^{2}\right) 0.999$ and limit of quantification was $0.005 \mathrm{mg} / \mathrm{kg}$. The results of method validation were satisfied Codex guideline. The results revealed that the developed and validated analytical method is possible for pyrimisulfan determination in agricultural product samples and will be used as an official analytical method.

요 약: 국내 신규 제초제로 등록된 pyrimisulfan에 대해 농산물 중 잔류실태를 조사하기 위하여 LC-MS/ $\mathrm{MS}$ 를 이용한 시험법을 개발하였다. Pyrimisulfan 시험법의 회수율은 현미, 감자, 감귤, 고추에서 $0.005 \mathrm{mg} / \mathrm{kg}$ 수준에서 88.7 99.3\%이고 $0.05 \mathrm{mg} / \mathrm{kg}$ 수준에서 각각 90.1 94.2\%였다. 회수율에 대한 모든 분석오차는 $10 \%$ 미만으로 Codex 잔류물질 분석 가이드라인에 만족하였다. ${ }^{16}$ 분석을 위한 기기 조건에서 pyrimisulfan의 정 량한계는 $0.005 \mathrm{mg} / \mathrm{kg}$ 이었으며 $0.01 \sim 1.0 \mathrm{mg} / \mathrm{kg}$ 범위에서 상관계수(R) 0.999 이상의 높은 직선성을 보여주 었다. 따라서 본 연구에서 개발된 잔류농약 시험법은 농산물을 대상으로 효과적인 시료 전처리 방법과 최 적의 정제 과정을 확립하여 다양한 농산물에 대한 잔류량 검출이 적당함을 확인할 수 있었다. 이와 같이 확립한 pyrimisulfan의 잔류시험법은 국제적 분석 기준을 만족할 뿐만 아니라 분석과정의 신뢰성 또한 확보 할 수 있어서 본 잔류농약 시험법은 공정시험법으로 사용 될 것이다.
\end{abstract}

Key words: pyrimisulfan, herbicide, agricultural commodities, LC-MS/MS

$\star$ Corresponding author

Phone : +82-(0)43-719-4207 Fax : +82-(0)43-719-4200

E-mail : jado@kfda.go.kr 


\section{1. 서 론}

제초제는 1980년대 이후 사용이 증가되기 시작하였 으며 초기에는 잔디에 처리하는 제초제와 sulfonylurea 계통의 제초제들이 사용되었다. 그러나 여러 종류의 잡초들이 1990년대 부터 sulfonylurea 계통의 제초제 에 대하여 저항성을 보이기 시작하여 현재 sulfonylurea 계통의 농약에 대한 저항성을 지닌 잡초에 대해서 다 른 종류의 제초제와 섞어서 사용해오고 있다. ${ }^{1}$ 우리 나라 역시 1999년부터 sulfonylurea계 제초제들에 대 한 저항성을 가진 물옥잠이 최초로 보고된 이후 ${ }^{2}$ 현 재까지 물달개비 ${ }^{3}$ 와 올챙이고랭이, ${ }^{4}$ 그리고 최근에는 서해안지역과 전북지역에 많이 확산되고 있는 물피 ${ }^{5}$ 와 강피 ${ }^{6}$ 까지 총 11 종의 잡초종이 계열의 제초제에 저항성이 있는 것으로 보고되었다. ${ }^{7}$ 이와 같은 제초 제의 저항성이 있는 잡초들의 발생으로 점점 세, 네 가지 이상의 복합성분들을 함유한 제초제들이 사용 되어 대부분 일회처리로 여러 종의 잡초종을 제거할 수 있는 제초제가 사용되고 있는 실정이다. 2010년, 일본에서 벼를 재배하는 논의 총 면적이 163 만 ha이 고 수도작하는 논에 일회 처리하는 제초제양은 총 수 도작 논의 면적과 동등한 양으로 조사되었다. 하지만 일본 농림수산성(Ministry of Agriculture, Forestry and Fisheries:MAFFP)의 가이드라인에서는 “특별 재배 벼” 의 경우 제초제의 종류와 사용량이 화학비료 총 량의 절반이 넘으면 안되어 제초제의 총 사용량을 감소시키 기 위해서 이러한 저항성 있는 잡초들을 없앨 수 있는 새로운 개념의 제초제 개발이 요구되었다. ${ }^{8}$ 이와 같은 이유로 개발된 pyrimisulfan (CAS No.221205-90-9, (RS)2'-(4,6-dimethoxy-pyrimidin-2-yl)hydroxymethyl-6'-methoxymethyl-1,1-difluoromethanesulfonanilide)은 일본 Kumiai chemical사에서 sulfonylurea계 제초제로 개발 한 농약으로 잔디 및 잡초에 제초의 역할이 탁월하면 서도 높은 선택성을 지니고 있어 작물에 대한 피해가 없고 벼로 전이 되는 양이 적은 농약으로 알려져 있으 며 분자구조와 물리화학적 특성을 Fig. 1 및 Table 2에 나타내었다. ${ }^{9}$ Sulfonylurea계 제초제는 발아 후 처리되 는 선택성 제초제로 식물의 필수 아미노산인 valine 및 isoluecine 등의 생합성에 관여하는 aceolacetate synthase

Table 1. Standards current state of affair

\begin{tabular}{cc}
\hline \hline Food commodity & Maximum Residue Limits $(\mathrm{mg} / \mathrm{kg})$ \\
\hline Rice & 0.05 \\
\hline
\end{tabular}

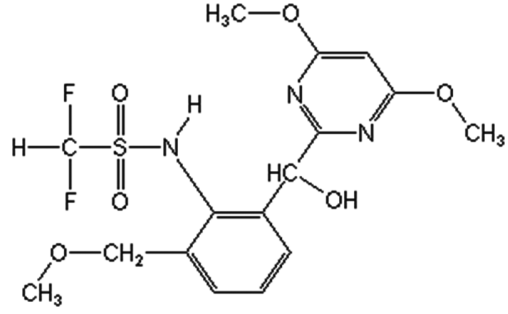

Fig. 1. Molecular structure of pyrimisulfan.

(ALS)나 acetohydroxyacid synthase (AHAS)를 저해함 으로써 고활성의 제초작용을 나타내는 것으로 주로 곡류나 옥수수 재배에 발생하는 다양한 잡초를 방제 하기 위하여 전면 살포 또는 토양처리로 사용된다고 보고되었다. 또한 작물 및 환경 중 잔류량은 살포 초 기에도 매우 낮으며 작물로 전이 되는 양도 적어 전 세계 및 국내에서의 잔류허용기준은 각각 0.02 0.3 $\mathrm{mg} / \mathrm{kg}$ 으로 엄격하게 설정되어 있고 수확물 중에서 매우 낮은 잔류수준까지 분석하여야 하는 어려움이 있다. ${ }^{10,11}$

이와 같이 sulfonylurea계 화합물의 특징을 가지고 개발된 pyrimisulfan 역시 잔류량이 적을 것으로 예상 되는 신제초제이다. 기계 이앙벼(어린모)의 일년생 및 다년생 잡초 방제를 위해 사용되는 농약으로 국내에 서는 2010년에 벼 재배를 위해 사용등록이 신청되었 으며, 2011년 8월에 잔류허용기준이 쌀 중 $0.05 \mathrm{mg} /$ $\mathrm{kg}$ 으로 제정 - 고시 되었다. ${ }^{12}$ 따라서 본 연구에서는 식품 중 pyrimisulfan의 안전관리를 위해 LC-MS/MS

Table 2. Physiochemical characteristics of pyrimisulfan

\begin{tabular}{|c|c|}
\hline Property & Content \\
\hline IUPAC name & $\begin{array}{l}(R S)-2 \text { '-[(4,6-dimethoxypyrimidin-2-yl) } \\
\text { (hydroxy)methyl]-1,1-difluoro-6'-(methoxy- } \\
\text { methyl)methanesulfonanilide }\end{array}$ \\
\hline CAS No. & $221205-90-9$ \\
\hline Classification & Sulfonanilide \\
\hline Boiling point & $550.8{ }^{\circ} \mathrm{C}(760 \mathrm{mmHg})$ \\
\hline Density & $1.48 \mathrm{~g} / \mathrm{cm}^{3}$ \\
\hline Log Pow ${ }^{*}$ & $\begin{array}{l}2.15\left(\mathrm{pH} 3,20{ }^{\circ} \mathrm{C}\right), 2.01\left(\mathrm{pH} 5,20{ }^{\circ} \mathrm{C}\right), 0.52 \\
\left(\mathrm{pH} 7,20{ }^{\circ} \mathrm{C}\right),-1.28\left(\mathrm{pH} 9,20{ }^{\circ} \mathrm{C}\right)\end{array}$ \\
\hline Vapor pressure & $\leq 2.1 \times 10^{-8}\left(\mathrm{~Pa}, 25{ }^{\circ} \mathrm{C}\right)$ \\
\hline Solubility & $\begin{array}{l}89.3 \mathrm{mg} / \mathrm{L}\left(\text { Deionized water, } 20{ }^{\circ} \mathrm{C}\right), 114 \\
\mathrm{mg} / \mathrm{L}\left(\mathrm{pH} 5,20{ }^{\circ} \mathrm{C}\right) \\
2,676 \mathrm{mg} / \mathrm{L}\left(\mathrm{pH} 7,20{ }^{\circ} \mathrm{C}\right), 8,438 \mathrm{mg} / \mathrm{L}(\mathrm{pH} \\
\left.9,20{ }^{\circ} \mathrm{C}\right)\end{array}$ \\
\hline
\end{tabular}

*n-Octanol/water partition coefficien

**Dissociation constant at $25{ }^{\circ} \mathrm{C}$. 
를 이용한 분석법을 개발하고자 하였다.

\section{2. 재료 및 방법}

\section{1. 표준시료 및 재료}

Pyrimisulfan 표준시료(99\%)는 바이엘(Bayer cropscience)사에서 제공받아 사용하였고, 분석에 사용한 검 체는 기준이 설정된 농산물인 쌀(현미) 외에 대표농 산물로 서류 중 감자, 과일류 중 감귤, 채소류 중 고 추를 추가 구매하여 분석하였다. 모든 재료는 회수율 시험재료로써 무농약, 친환경 제품을 대형유통마트에 서 구입하였으며 상하였거나 원형이 훼손되지 않은 것에 한하여 구입하였다. 구입후 즉시 잔류농약분석 용 식품 전처리 방법에 준하여 균질화하여 밀봉된 용 기에 담아 $-50{ }^{\circ} \mathrm{C}$ 에 보관하면서 실험에 사용하였다.

\section{2. 시약 및 장비}

분석시 사용되는 dichloromethane과 hexane, acetone, acetonitrile 등은 HPLC grade로써 Merck (Darmstadt, Germany)에서 구입하여 사용하였다. Sodium chloride 와 sodium sulfate anhydrous는 Wako (Osaka, Japan) 로부터 acetic acid와 hydrochloric acid는 Sigma-Aldrich (St. Louis, MO, USA)로부터 구입하였으며, 실리카 (SPE-silica, $6 \mathrm{cc}, 500 \mathrm{mg}$ )는 Phenomenex (Torrance, USA) 로부터 구입하여 사용하였고 본 실험에 사용된 기타 일반시약은 특급시약을 사용하였다.

\section{3. 표준용액조제}

Pyrimisulfan 표준시료는 $10.10 \mathrm{mg}$ 을 acetonitrile $20 \mathrm{~mL}$ 에 용해하여 $500 \mu \mathrm{g} / \mathrm{mL}$ 의 표준원액을 조제하 여 갈색병에 담아 $4{ }^{\circ} \mathrm{C}$ 에서 보관하였다. 분석시에는 표준원액을 acetonitrile로 희석하여 $0.01,0.05,0.1$, 0.5 및 $1.0 \mu \mathrm{g} / \mathrm{mL}$ 의 농도로 조제하여 모두 갈색병에 담아 실험에 사용하였다.

\section{4. 분석기기}

식품 중 pyrimisulfan을 분석하기 위하여 LC-MS/ MS (Quattro Premier XE, Waters, USA)를 사용하였고 컬럼은 HPLC Packed column UG120 $\mathrm{C}_{18}(150 \mathrm{~mm} \times 2.0$ $\mathrm{mm}$ I.D., $3 \mu \mathrm{m}$, shiseido, Japan)을 사용하였다.

\section{5. 실험방법}

2.5.1. 시료 중 대상물질 추출 및 정제

검체 $1 \mathrm{~kg}$ 을 혼합하고 분쇄(곡류 및 콩류의 경우
표준체 $420 \mu \mathrm{m}$ 를 통과시킨 후)하여 $20 \mathrm{~g}$ 을 정밀히 달아 균질기 용기에 넣고 acetonitrile $100 \mathrm{~mL}$ 를 가하여 추출하였으며, 검체 중 현미의 경우 습윤화를 위해 물 $20 \mathrm{~mL}$ 를 넣고 1시간 동안 정치시킨 후 acetonitrile 100 $\mathrm{mL}$ 를 가하여 3 분간 균질화하였다. 이를 부흐너 깔때기 로 흡입여과하고 잔류물을 acetonitrile $40 \mathrm{~mL}$ 로 씻어내 려 $500 \mathrm{~mL}$ 감압농축플라스크에 받아 이 여액을 40 ${ }^{\circ} \mathrm{C}$ 이하의 수욕상에서 약 $10 \mathrm{~mL}$ 가 될 때까지 감압농축 하고 $1 \mathrm{~N}$ hydrochloric acid $2 \mathrm{~mL}$ 를 가하여 산성화한 후, $500 \mathrm{~mL}$ 분액깔때기에 옮겼다. 이에 dichloromethane $100 \mathrm{~mL}$, 포화염화나트륨 $40 \mathrm{~mL}$ 를 가한 후 5분간 격 렬하게 진탕하고 다시 물층에 dichloromethane 50 $\mathrm{mL}$ 를 가하여 위와 같이 추가 1 회 반복하여 유기용매 층을 합한 후 sodium sulfate anhydrous $15 \mathrm{~g}$ 에 통과시 켜 탈수하여 감압농축플라스크에 취해 $40{ }^{\circ} \mathrm{C}$ 이하에서 감압농축한 후 잔류물에 hexane:acetone $(90: 10, \mathrm{v} / \mathrm{v})$ 용 액 $10 \mathrm{~mL}$ 를 가하여 용해하였다. Hexane:acetone (90:10, $\mathrm{v} / \mathrm{v}$ ) 용액에 녹인 추출액을 미리 hexane $10 \mathrm{~mL}$ 로 활성 화한 실리카(SPE-silica, $6 \mathrm{cc}, 500 \mathrm{mg}$ ) 카트리지에 가하 여 흘려서 버리고 여기에 다시 hexane:acetone (90:10, v/ v) 용액 $5 \mathrm{~mL}$ 를 가하여 유출시켜 버렸다. 고정상 상단 이 노출되기 전에 hexane:acetone $(70: 30, \mathrm{v} / \mathrm{v})$ 용액 10 $\mathrm{mL}$ 를 가하여 용출시켜 감압농축플라스크에 받아 40 이하 수욕상에서 감압농축한 후 잔류물을 $0.1 \%$ acetic acid in water $/ 0.1 \%$ acetic acid in acetonitrile $(60 / 40, \mathrm{v} / \mathrm{v})$ 용액 $2 \mu \mathrm{mL}$ 에 용해시킨 후 $0.2 \mu \mathrm{m}$ 멤브레인 필터로 여 과하여 시험용액으로 하였다. 기기분석은 LC-MS/MS 를 이용하였고 기기조건은 Table 3에 나타내었다. 상기 와 같이 확립된 pyrimisulfan의 시험법을 flow chart로 나타내었다(Fig. 2).

Table 3. Analytical conditions of LC-MS/MS for pyrimisulfan

\begin{tabular}{ll}
\hline \hline \multicolumn{1}{c}{ Instrument } & $\begin{array}{l}\text { LC-MS/MS (US/Quattro Premier XE, } \\
\text { Waters, USA) }\end{array}$ \\
\hline Column & $\begin{array}{l}\text { UG120 } \mathrm{C}_{18}(150 \mathrm{~mm} \times 2 \mathrm{~mm} \text { i.d. } 3 \mu \mathrm{m}, \\
\text { Shiseido, Japan) }\end{array}$ \\
Mobile phase & $\begin{array}{l}0.1 \% \text { acetic acid in water } / 0.1 \% \text { acetic } \\
\text { acid in ACN }(60 / 40, \mathrm{v} / \mathrm{v})\end{array}$ \\
Flow rate & $0.3 \mathrm{~mL} / \mathrm{min}$ \\
Column temperature & $40{ }^{\circ} \mathrm{C}$ \\
Injection volume & $2 \mu \mathrm{L}$ \\
Ionization & Electrospray ionization (ESI) positive- \\
Cone voltage & ion mode \\
Collision energy & $20 \mathrm{~V}$ \\
\hline
\end{tabular}




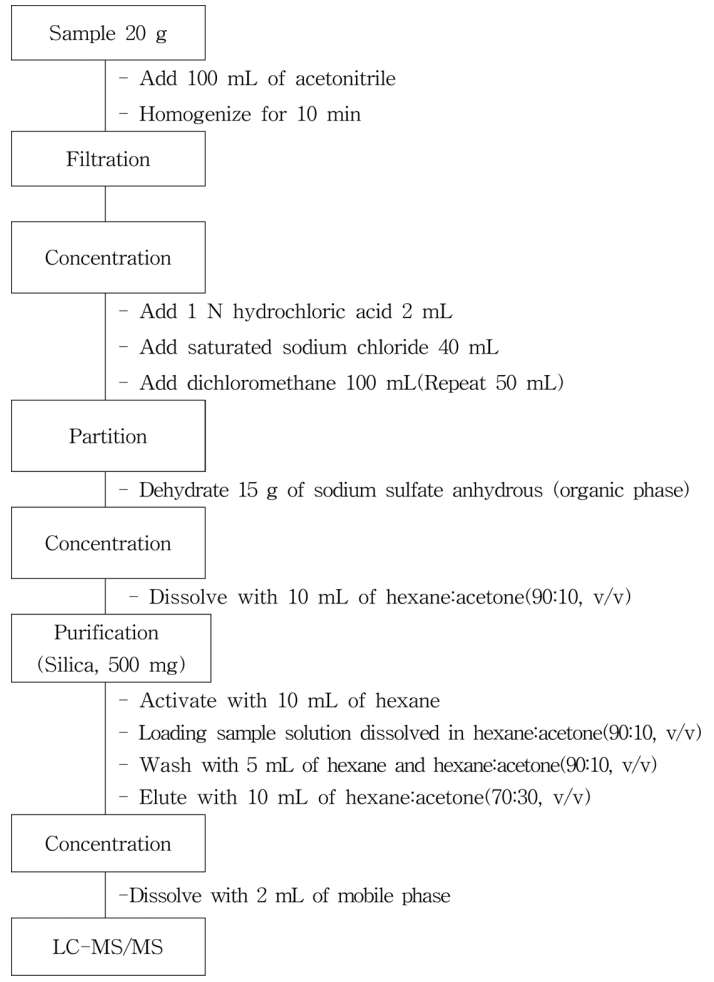

Fig. 2. Flow chart for pyrimisulfan analysis.

\subsection{2. 회수율 측정}

분석방법에 따른 회수율을 측정하기 위하여 각 농 산물(현미, 감귤, 감자, 고추)에 표준용액을 첨가하여 분석하였다. 수분함량이 낮은 시료(현미)의 경우에는 물을 첨가하여 수화하고 난 후에 표준용액을 첨가하 였다. 이와 같이 준비된 시료를 2시간 방치하여 처리 농약이 조직 내부로 충분히 침투할 수 있도록 하여 사용하였다. 각 시료 중 pyrimisulfan의 처리농도는 $0.005,0.01$ 및 $0.05 \mathrm{mg} / \mathrm{kg}$ 이 되도록 하였으며 회수 율 측정은 각각의 농도 및 시료에 대하여 3 번 반복하 여 평균과 상대표준편차를 계산하였다.

\section{3. 결과 및 고찰}

\subsection{Pyrimisulfan의 기기 분석 조건 확립}

Pyrimisulfan은 휘발성이 $\leq 2.1 \times 10^{-8} \mathrm{~Pa}$ 로 낮고 $\log \mathrm{P}_{\mathrm{ow}}$ 가 $2.15\left(\mathrm{pH} 3,20{ }^{\circ} \mathrm{C}\right), 2.01\left(\mathrm{pH} 5,20{ }^{\circ} \mathrm{C}\right), 0.52$ $\left(\mathrm{pH} \mathrm{7,} 20{ }^{\circ} \mathrm{C}\right),-1.28\left(\mathrm{pH} 9,20{ }^{\circ} \mathrm{C}\right)$ 로 $\mathrm{pH}$ 조건에 따라 염기성으로 될수록 극성도가 증가하는 특성을 가지고 있음을 알 수 있으며 극성이 높은 화합물로 비해리성을 나타내고 있다. 분자량은 $419.41 \mathrm{~g} / \mathrm{mol}$
로 큰편이며 구조적 특성을 살펴보면 $250 \mathrm{~nm}$ 의 특 정 UV 파장대에서 흡광성이 높은 물질로 HPLC$\mathrm{UVD}$ 로도 분석이 가능하나 예비실험결과 분석 감도 가 크지 않아 회수율 실험에서 낮은 회수율과 낮은 농도의 물질의 검출이 어려운 것을 확인 할 수 있었 다. 뿐만 아니라 앞에서도 언급한 바와 같이 sulfonylurea 계통의 농약 특성상 잔류량이 낮아 잔 류허용기준 역시 낮은 점을 감안하여 미량까지 검출 할 수 있는 LC-MS/MS를 적용하여 분석법을 개발 하였다. 또한 sulfonylurea계 대상성분들은 그 분자 구조에서도 예상할 수 있듯이 sulfonyl group의 강한 전자끌기 특성으로 인하여 인접한 nitrogen에 결합된 hydrogen이 해리, $\mathrm{pKa}$ 가 2.3 5.5 범위인 약산성 화 합물들이다. 따라서 pyrimisulfan은 휘발성이 낮고 극성이 높으며 수용액 중에서 해리하는 약산성의 특 성을 반영하므로 유기 용매 및 $\mathrm{pH}$ 조건을 달리한 유기용매/수용액 혼합액 중에서 비이온/이온 형태가 공존 또는 상호 변환되는 상태로 이동하므로 분석이 어려운 단점이 있다. Ion-pair chromatography법 또 는 이온억압법이 가능하지만 분석 조건과 용매조성 에 영향을 많이 받는 단점이 있고 분석시 재현성이 낮은 점을 감안하여 시험법을 개발하였다. 또한 pyrimisufan은 분자 내에 ion pair를 보유한 질소원 자가 다수 존재하여 protonation이 용이하므로 이온 화법으로는 ESI, positive ion법이 최선이다. Sulfonyl group에 인접한 nitrogen에 결합된 hydrogen이 해리되 는 특성을 이용하여 ESI negative-ion법도 가능하나 대 상성분들의 크로마토그래피 특성 개선을 위하여 약 산성의 이동상을 이용하므로 이온화가 억압되어 deprotonation에 의한 충분한 감도를 얻기 어렵다. ${ }^{13}$

이렇게 확립된 분석 조건에서 얻은 표준물질의 크 로마토그램을 Fig. 3에 나타내었으며 기기에서 높은 직선성을 확인 할 수 있었다. 기기 분석조건 중 주입 량 선정은 pyrimisulfan의 기기적 감도가 좋아서 2 $\mu \mathrm{L}$ 를 주입 하였을 때도 $\mathrm{S} / \mathrm{N}=4.32(>3.0)$ 으로 검출한 계가 높아 주입량을 2 ul로 결정하였다(Fig. 4 6). 이때 이동상 조건은 $0.1 \%$ formic acid 함유한 acetonitrile과 $0.1 \%$ formic acid 함유한 water를 적절한 농도구배조 건으로 선정하였으며, 유속은 $0.3 \mathrm{~mL} / \mathrm{min}$ 이었다. LC-MS/MS 분석을 위한 분자량 범위는 $50 \sim 500 \mathrm{~m} / \mathrm{z}$ 으로 이온화가 쉽게 이루어지는 구조적 특성을 감안 하여 기기의 검출 감도가 높아지는 이온을 선정하였 다. 그 결과 $370 \mathrm{~m} / \mathrm{z}$ 와 $255 \mathrm{~m} / \mathrm{z}$ 가 최적 특성이온으 로 선정되었으며 주요 특성이온의 $\mathrm{m} / \mathrm{z}$ 값은 Table 4 

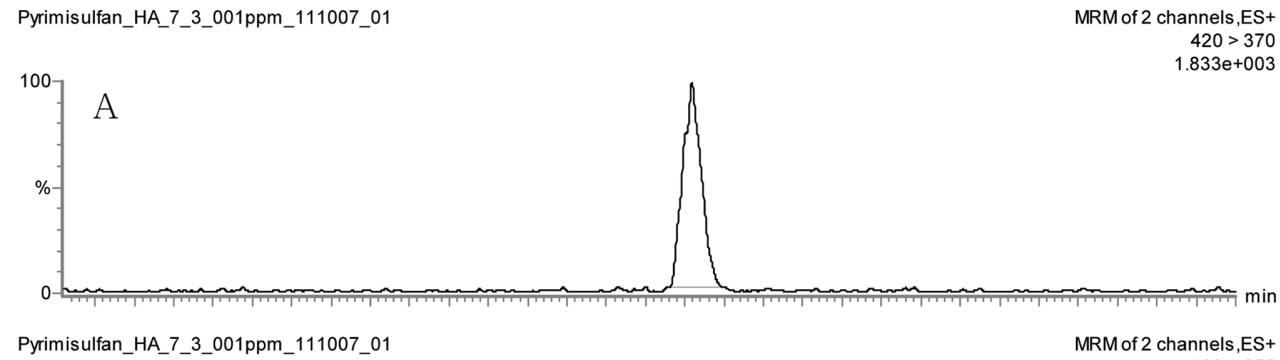

MRM of 2 channels, ES + $420>255$
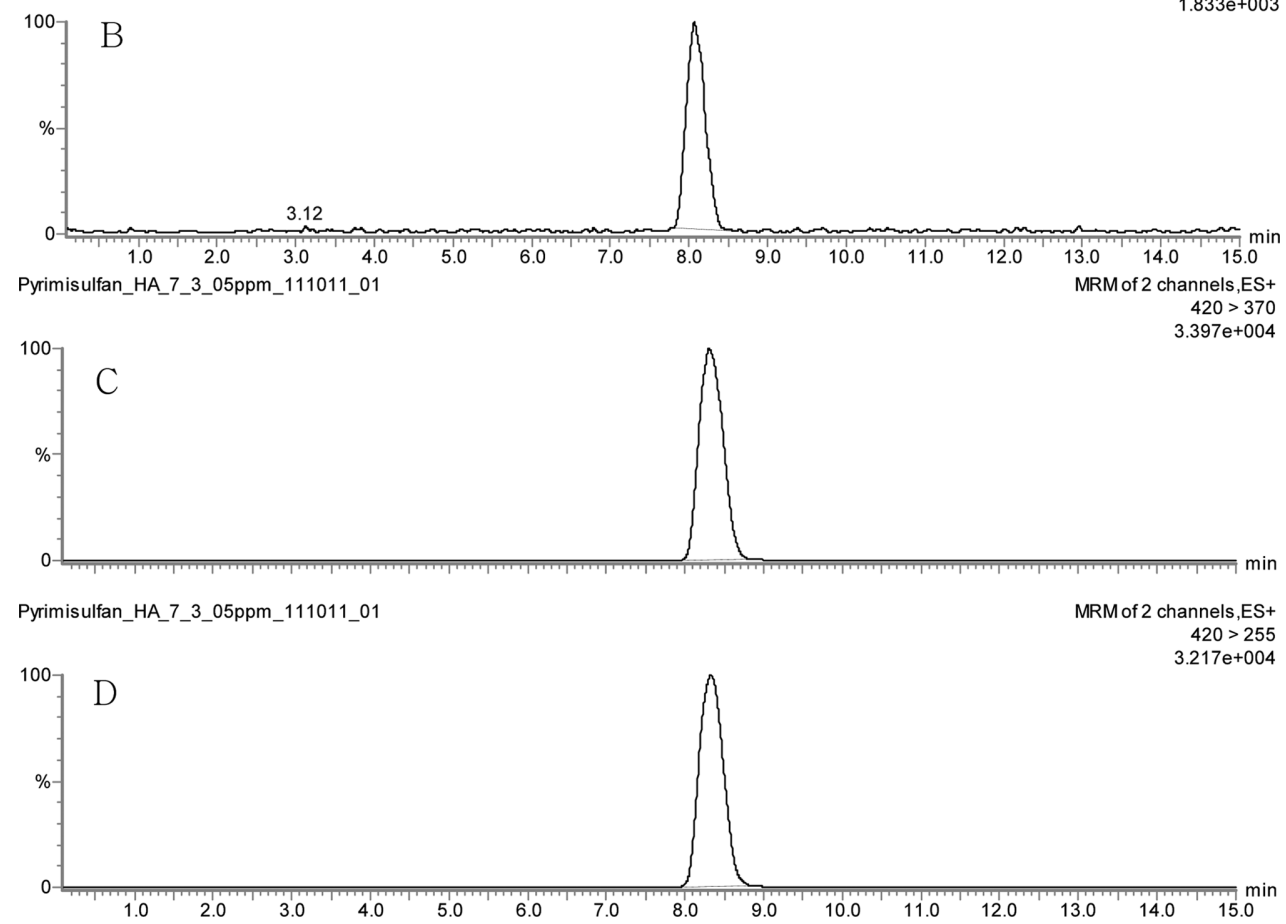

Fig. 3. LC-MS/MS chromatograms of pyrimisulfan standard at $\mathrm{A}(420 \triangleright 370)$ and $\mathrm{B}(420 \triangleright 255) ; 0.01 \mathrm{mg} / \mathrm{kg}, \mathrm{C}(420>370)$ and $\mathrm{D}(420>255) ; 0.5 \mathrm{mg} / \mathrm{kg}$.

에 나타내었다.

본 연구에서 확립한 시험용액 조제 및 기기분석법을 이용하여 검체 중 pyrimisulfan의 정량한계를 구한 결과 검출한계는 최소검출량이 $0.05 \mathrm{ng}(\mathrm{S} / \mathrm{N}=3)$ 이었고 아래 의 계산식에 따라 $0.0025 \mathrm{mg} / \mathrm{kg}$ 으로 나타났다. 정량한 계는 최소검출량이 $0.1 \mathrm{ng}(\mathrm{S} / \mathrm{N}=10)$ 으로 아래의 계산식 에 따라 $0.005 \mathrm{mg} / \mathrm{kg}$ 이었다.

\section{검출한계 $(\mathrm{mg} / \mathrm{kg})$}

$=$ 최소검출량 $(\mathrm{ng}) \times \frac{1}{\text { 시료량 }(\mathrm{g})} \times \frac{\text { 최종희석부피 }(\mathrm{mL})}{\text { 시료 주입량 }(\mu \mathrm{L})}$

$=0.05(\mathrm{ng}) \times \frac{1}{20(\mathrm{~g})} \times \frac{2(\mathrm{~mL})}{2(\mu \mathrm{L})}=0.0025$
정 량한계 $(\mathrm{mg} / \mathrm{kg})$

$=$ 최소검출량 $(\mathrm{ng}) \times \frac{1}{\text { 시료량 }(\mathrm{g})} \times \frac{\text { 최종희석부피 }(\mathrm{mL})}{\text { 시료 주입량 }(\mu \mathrm{L})}$

$=0.1(\mathrm{ng}) \times \frac{1}{20(\mathrm{~g})} \times \frac{2(\mathrm{~mL})}{2(\mu \mathrm{L})}=0.005$

\subsection{Pyrimisulfan의 추출 및 정제 조건 확립}

농산물 검체로부터 극성 대상성분을 추출하기 위 한 용매로는 acetone과 methanol이 일반적으로 많이 사용되고 있지만 본 실험에서는 추출 용매로 사용된 acetonitrile은 US FDA법이나 AOAC법 등 이미 많 은 연구자들에 의하여 유사 특성의 극성농약 추출에 그 효율과 재현성이 인정되었고 예비실험에서도 확 


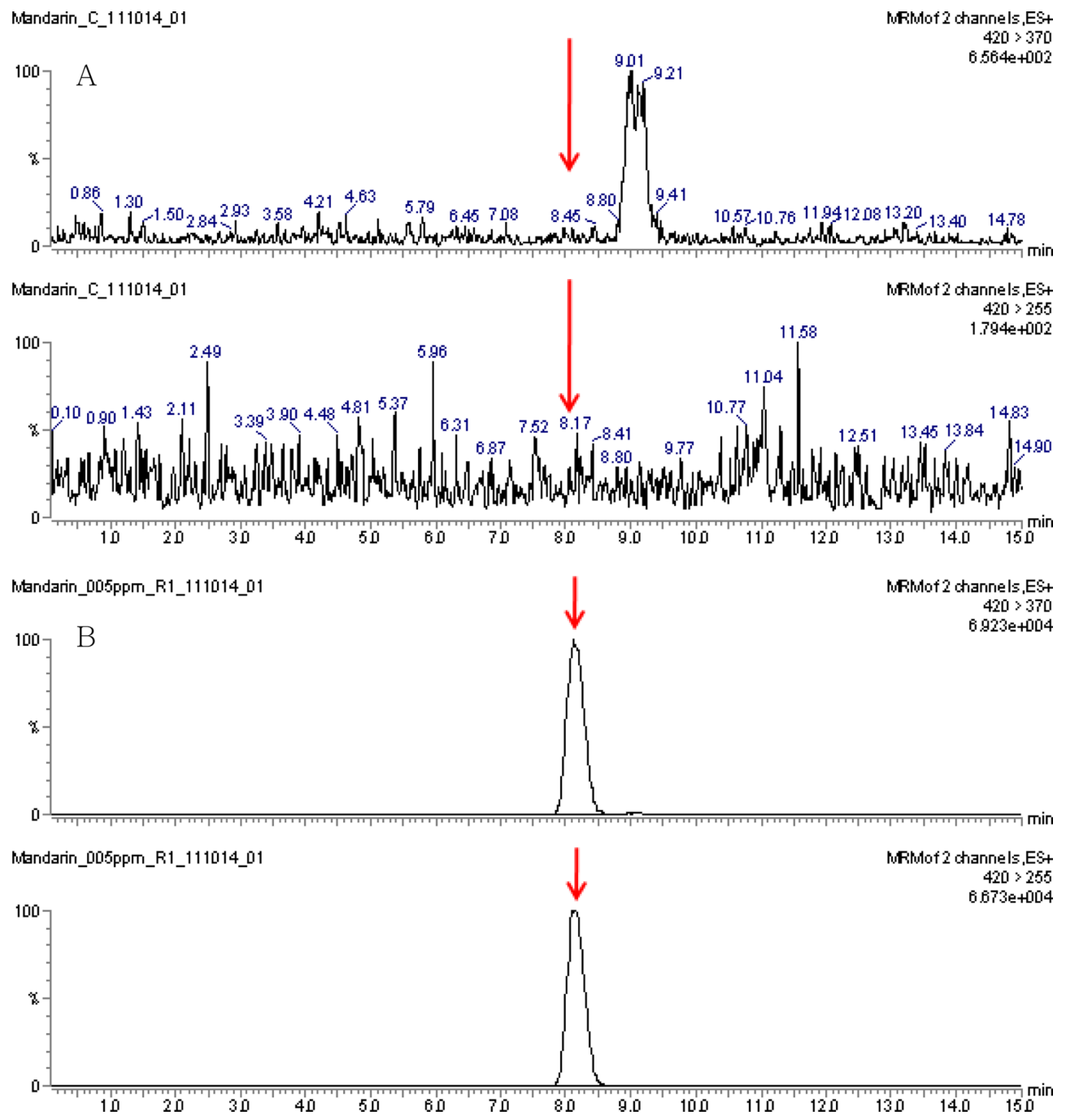

Fig. 4. LC-MS/MS chromatograms of mandarin A; control, B; at $0.05 \mathrm{mg} / \mathrm{kg}$.

인하였듯이 acetone과 methanol에 비하여 상대적으 로 적은양의 불순물이 추출되므로 추출 이후의 정제 과정이 간편한 장점이 있다. 추출 후 acetonitrile과 같 은 유기용매 가용성 조건과 함께 추출, 여과 후 $1 \mathrm{~N}$ $\mathrm{HCl}$ 을 첨가하여 약산성화하여서 대상성분의 이온화 를 억압하였으며 추출물로부터 불순물을 제거하기 위 하여 액-액 분배법을 수행하였는데 pyrimisulfan은 약 산성의 해리 가능성 화합물이므로 알칼리조건에서는 수용성, 산성에서는 유용성의 특성을 나타내므로 검 체의 추출액의 산도를 약산성으로 조절하여 물질을 유용성인 비해리 형태로 만들어 주며 $\mathrm{NaCl}$ 를 첨가하 여 이온세기를 보다 증대시킨 조건에서 dichloro- methane으로 2회 분배하여 pyrimisufan을 우수한 분 배효율로 회수할 수 있었다. 특히 sulfonylurea계통의 화합물들이 강산, 강알칼리조건에서 쉽게 분해되므로 $\mathrm{pH}$ 는 약산범위를 넘지 않도록 주의하여야 했다. 이러 한 추출 조건에 의한 추출액은 추가 정제법으로 SPEsillica의 흡착크로마토그래피법으로 결정하였다. 이는 pyrimisufan의 약산성의 성질을 이용하여 silica표면의 hydrolxyl 작용기와 흡착, 분배가 용이하게 이루어질 수 있는데 반하여 florisil과 $\mathrm{NH}_{2}$ 의 경우는 약산성 물질의 강한 흡착으로 인하여 회수율 및 정제 재현성이 떨어 짐을 확인 할 수 있었다. SPE-silica를 이용하면서 비극 성인 hexane으로 우선 비극성 물질들을 제거한 다음 

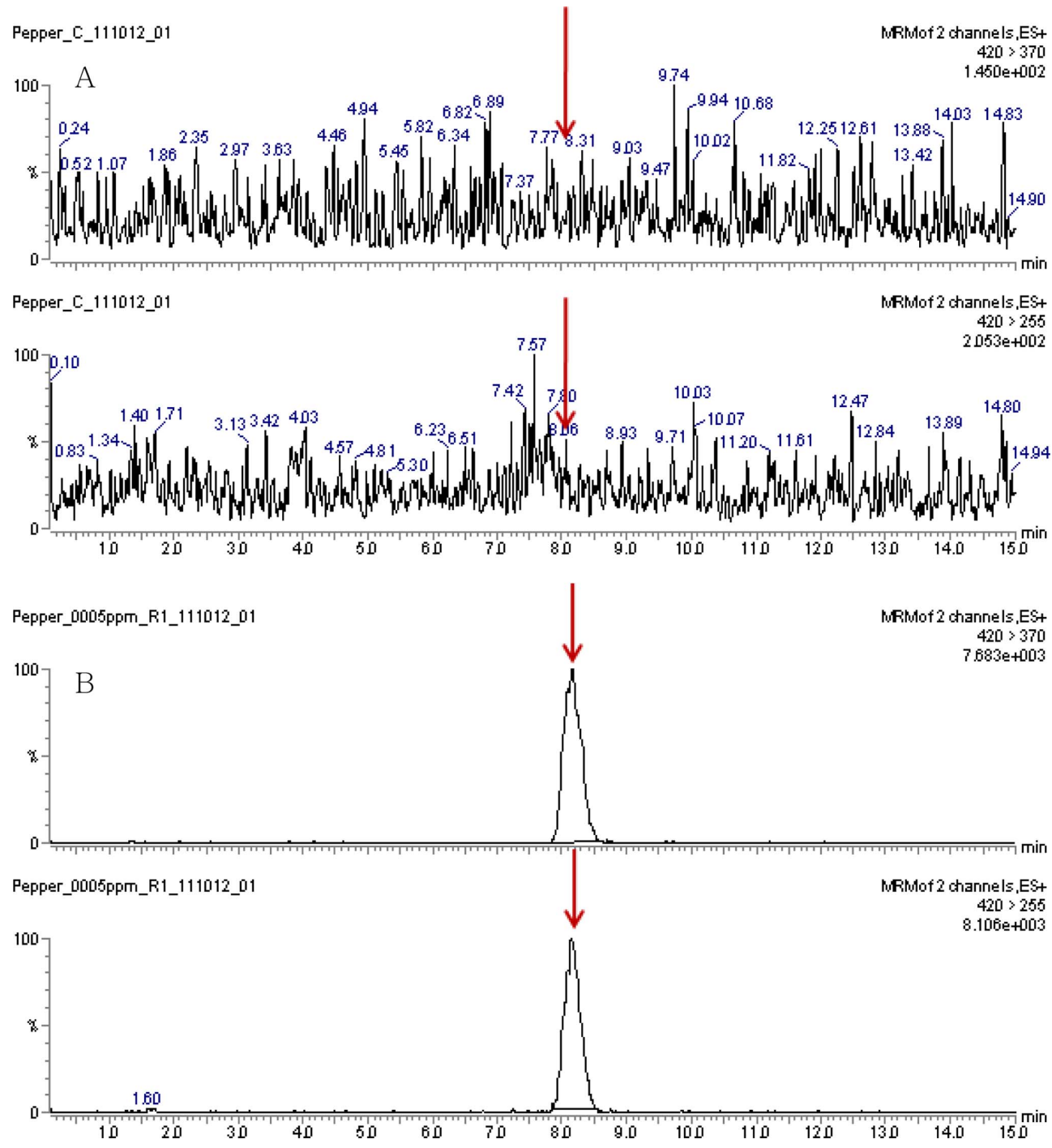

Fig. 5. LC-MS/MS chromatograms of pepper A; control, B; at $0.005 \mathrm{mg} / \mathrm{kg}$.

hexane:acetone $(90: 10, \mathrm{v} / \mathrm{v})$ 용액 $5 \mathrm{~mL}$ 를 가하여 유출시 켜 검체의 간섭물질들을 제거하고 hexane:acetone $(70: 30, \mathrm{v} / \mathrm{v})$ 용액 $10 \mathrm{~mL}$ 를 가하여 용출시켜 pyrimisufan 을 모두 회수할 수 있었다. 이러한 추출 및 정제 조건을 통해 농산물 검체(현미, 감자, 감귤, 고추) 모두 간섭 물질의 방해 없이 pyrimisufan을 회수 할 수 있었다 (Fig. 4 6).

\subsection{Pyrimisulfan의 시험법의 검증 및 회수율}

Pyrimisufan의 선택성은 앞에서 보는 바와 같이 무 처리 검체 중 pyrimisufan과 같은 머무름 시간을 갖
는 어떤 방해물질도 검출되지 않음을 확인할 수 있었 고 검체 중 pyrimisufan을 분석하기 위한 위 추출 정 제 조건이 높은 분리능과 선택성을 가짐을 확인할 수 있었다. 다음으로 직선성을 확인하기 위하여 0.05 , $0.1,0.5$ 그리고 $1.0 \mu \mathrm{g} / \mathrm{mL}$ 의 범위에서 분석한 결과 상관계수 $\left(\mathrm{R}^{2}\right)$ 는 0.999 이상으로 높은 직선성과 재현 성을 보여주었다(Fig. 7). 시험법의 정확성을 평가하 기 위하여 처리농도 0.005 와 $0.01,0.05 \mathrm{mg} / \mathrm{kg}$ 에서 회수율 시험을 3 회 반복 수행한 결과를 Table 5에 나 타내었다. 회수율 결과 모든 검체에서 모두 높은 재 현성과 선택성을 확인 할 수 있었고 회수율도 


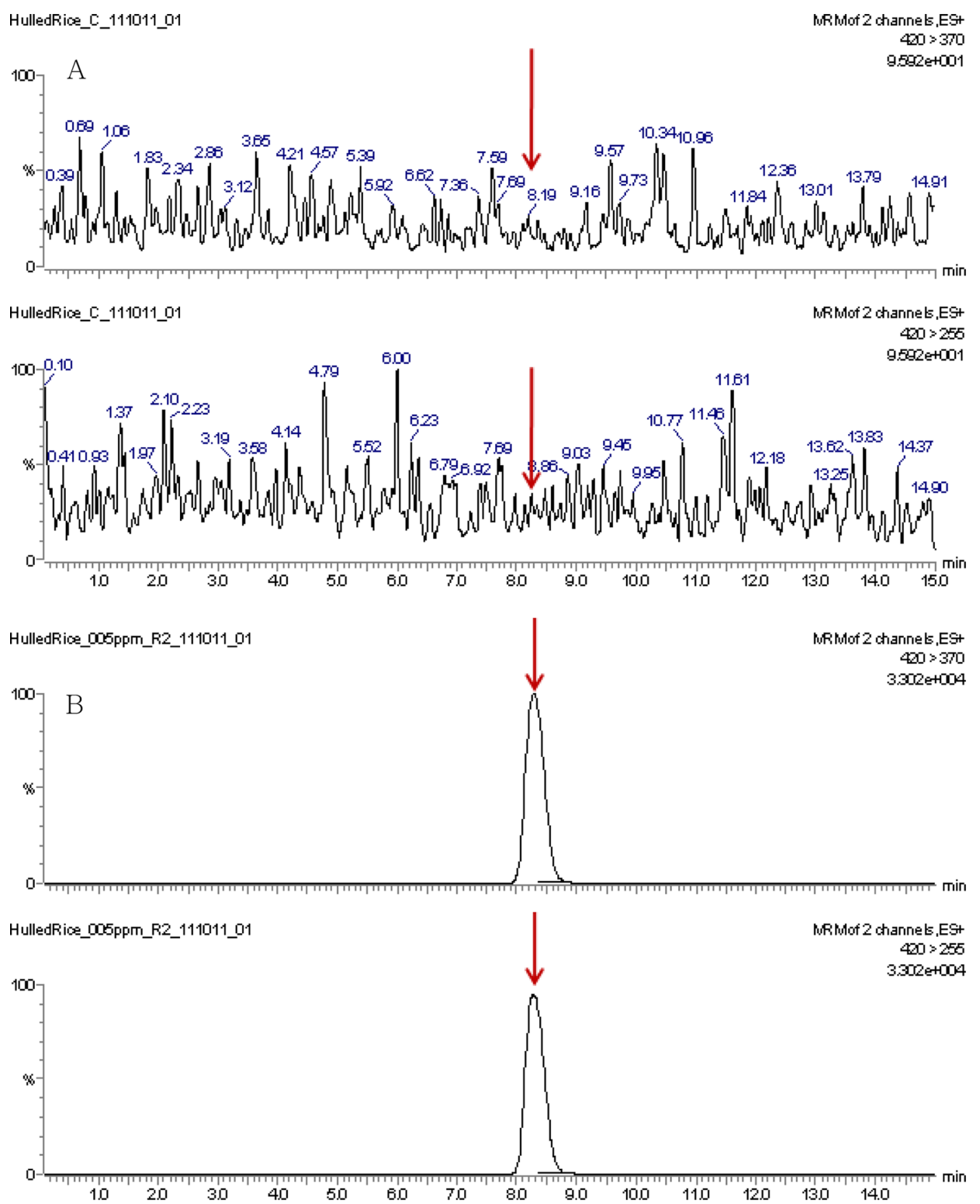

Fig. 6. LC-MS/MS chromatograms of hulled rice A; control, B; at $0.05 \mathrm{mg} / \mathrm{kg}$.

Table 4. Selected-ion of LC-MS/MS for pyrimisulfan

\begin{tabular}{cccc}
\hline \hline $\begin{array}{c}\text { Retention time } \\
(\mathrm{min})\end{array}$ & $\begin{array}{c}\text { Precursor } \\
\text { ion }(\mathrm{m} / \mathrm{z})\end{array}$ & $\begin{array}{c}\text { Fragment } \\
\text { ion }(\mathrm{m} / \mathrm{z})\end{array}$ & $\begin{array}{c}\text { Collision } \\
\text { energy }(\mathrm{V})\end{array}$ \\
\hline \multirow{2}{*}{8.1} & 420 & 370 & 20 \\
& 4255 & 25 \\
\hline
\end{tabular}

88.7 107.3\%로 높은 회수율을 보여주었다. 또한 상대 표준편차는 $10 \%$ 이하로 조사되었으며 ${ }^{15}$ 현미, 감자,
감귤, 고추 모두 무처리 시료군에서 pyrimisulfan과 같은 머무름 시간을 갖는 어떤 방해물질도 검출되지 않아 본 시험법은 pyrimisufan을 분석하기에 높은 분 리능과 선택성을 가짐을 확인 할 수 있었다. 본 연구 에서 적용한 추출 및 정제 방법이 농산물 중 잔류하 는 pyrimisulfan을 분석하는데 적합함을 확인 할 수 있었다. 또한 $0.005 \mathrm{mg} / \mathrm{kg}$ 처리구에서도 회수율이 높 은 점을 확인하였으며 그 결과 식품 중 잔류량이 적 은 시료의 경우에도 분석에 어려움이 없을 것으로 판 


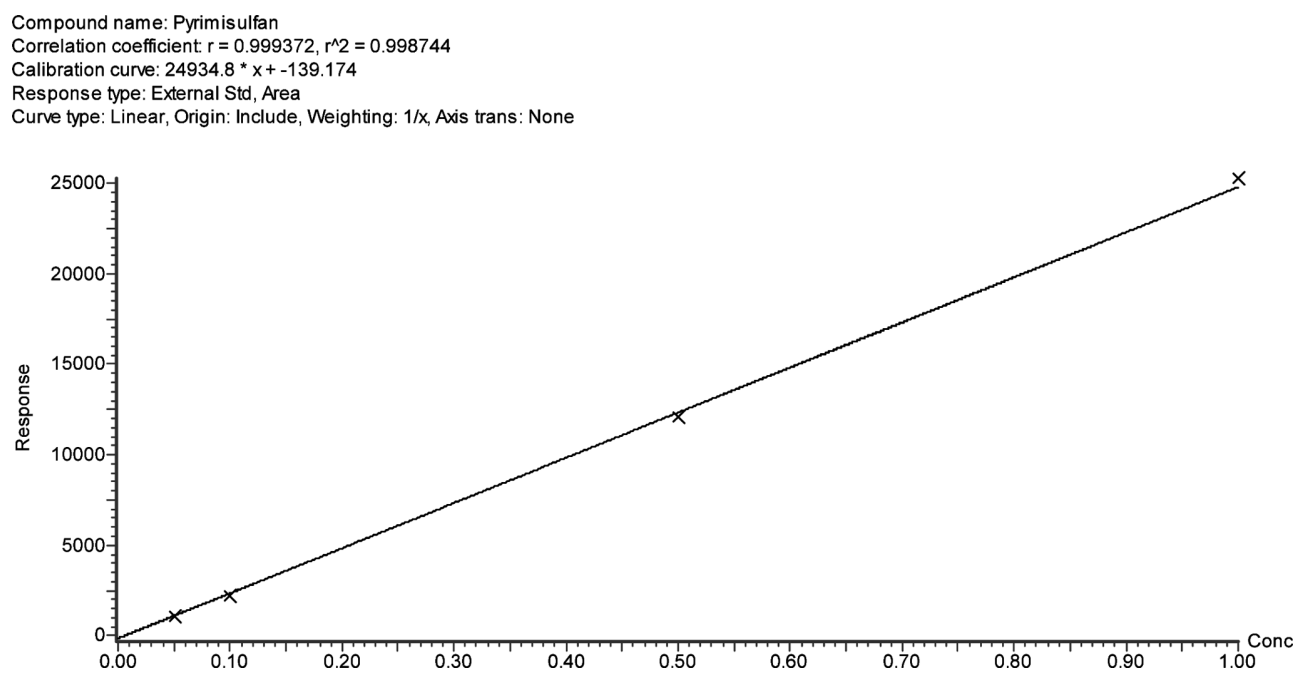

Fig. 7. Calibration curve of pyrimisulfan standard using LC-MS/MS.

Table 5. Validation results of analytical method for pyrimisulfan in food samples

\begin{tabular}{ccc}
\hline \hline Sample & $\begin{array}{c}\text { Fortification } \\
(\mathrm{mg} / \mathrm{kg})\end{array}$ & $\begin{array}{c}\text { Recovery }^{*} \\
(\%)\end{array}$ \\
\hline \multirow{3}{*}{ Hulled rice } & 0.005 & $88.7 \pm 6.8$ \\
& 0.01 & $107.3 \pm 4.5$ \\
& 0.05 & $94.2 \pm 6.4$ \\
\hline \multirow{3}{*}{ Mandarin } & 0.005 & $92.7 \pm 3.1$ \\
& 0.01 & $96.3 \pm 1.2$ \\
Pepper & 0.05 & $92.5 \pm 2.9$ \\
& 0.005 & $97.3 \pm 3.1$ \\
& 0.01 & $98.0 \pm 2.9$ \\
Potato & 0.05 & $91.4 \pm 2.7$ \\
\hline
\end{tabular}

*Mean values of triplicates with standard deviation.

단된다.

\section{감사의}

본 연구는 2011년도 식품의약품안전청의 연구개발 비(11161식품안034)로 수행되었으며, 이에 감사드립 니다.

\section{참고문헌}

1. A. Uchino, S. Ogata, H. Kohara and H. Watanabe, Weed
Biology and Management, 7(1), 89-96 (2007).

2. T. S. Pack, S. K. Chang and K. Y. Kim, Kor. J. Weed Sci., 19(1), 340-344 (1999).

3. O. D. Kwon, Y. I. Kuk, S. H. Cho H. R. Shin, Kor. J. Weed Sci., 29(3), 251-260 (2009).

4. Y. I. Kuk, O. D. Kwon and I, B. Im, Kor. J. Weed Sci. 22(3), 296-305 (2002).

5. S. H. Im, M. W. Park and D. S. Kim, Kor. J. Weed Sci 29(2), 178-184 (2009).

6. T. S. Park, Y. I. Ku and J. K. Ko, Kor. J. Weed Sci. 30(3), 291-299 (2010).

7. M. S. Park, Y. S. Park and J, D. Lee, Kor. J. Weed Sci. 31(2), 192-198 (2011).

8. Staristics of Agriculture, Forestry and Fisheries, MAFF. 2010.

9. T. Yishimura, M. Nakatani, S. Asakura, R. Hanai and S. Kuwahara, J. Pesticide Sci., 36(2), 212-220 (2011).

10. S. Asakura, M. Hiraoka, J. Pestic. Sci., 37(1), 62-68 (2012).

11. S. Asakura, H. Kawasaki and M. Hiraoka, $23^{\text {rd }}$ Asianpacific weed science society conference The sebel cairns, 26-29 (2011).

12. Y. D. Lee, 'Handbook for the pesticide residue analytical methods of Food Code Index', 3rd Ed, KFDA, 2012.

13. W. Horwits and G. W. Latimer, 'AOAC' USA, 2000.

14. US FDA, 'Pesticide Analytical Manual', Vol1: Multi 
residue Method, 3rd Ed, FDA, 1999

15. CODEX Alimentarius Commission. JOINT FAO/WHO FOOD STANDARDS PROGRAMME 35th Session
(2012).

16. CODEX Guidelines on good laboratory practice in residue analysis CAC/GL 40, (1993). 